\title{
Coaches' Perceptions and Intentions Towards Entrepreneurship
}

\author{
Yeliz Eratlı Şirin ${ }^{1}$ \\ ${ }^{1}$ School of Physical Education and Sports, CukurovaUniversity, Adana, Turkey \\ Correspondence: Yeliz Eratlı Şirin, School of Physical Education and Sports, Sports Management Department, \\ CukurovaUniversity, Adana, Turkey. E-mail: yelizsirin75@gmail.com
}

$\begin{aligned} & \text { Received: February 13, } 2019 \\ & \text { Accepted: March 10, } 2019 \quad \text { Online Published: March 25, } 2019 \\ & \text { doi:10.5539/jel.v8n2p271 }\end{aligned}$ URL: https://doi.org/10.5539/jel.v8n2p271

\begin{abstract}
In this study, it was aimed to examine the entrepreneurial characteristics of the coaches in terms of demographic variables. The study was designed in a descriptive model and quantitatively.The sample consisted of a total of 130 coaches of 38 females, 92 males. "Entrepreneurship Scale" was used as data collection tool which is developed by Deveci and Çepni (2015). Data were not normal distribution. Therefore, non-parametric Mann-Whitney U test and Kruskal-Wallis H tests were used. Descriptive statistics were also used. In the study, it was determined that coaches had middle and upper level entrepreneurship features and there were no differences in gender and level of coaching according to demographic variables. There was also a significant difference in risk taking and self-confidence subscales according to coaching years. As a result, according to demographic variables, risk taking and self-confidence are affected by the coaching year.
\end{abstract}

Keywords: coach, entrepreneurship, risk taking, self-confidence

\section{Introduction}

One of the indicators of economic wellfare in today's changing and developing world is entrepreneurship. The place of entrepreneurship in ensuring economic mobility is big and important. For this reason, it is a necessity to address entrepreneurship in all areas of production, services and activities in the economic sense. One of these areas is sports, because sports has become a major industry today and has the qualifications to respond to the interests of entrepreneurs in terms of production of sports equipment, marketing, facilities as well as service delivery. There is not much difference between the entrepreneurship in the sports sector and entrepreneurship in other sectors. As in every field, triggering entrepreneurship in the field of sports will be realized by the individuals who want to meet the interests and needs in this area and to reach economic prosperity in this way. Of course, it is necessary to have entrepreneurial features in order to realize this. The first thing that comes to mind when entrepreneurship is in question is openness to innovation, creativity and self-confidence. Because one of the basic conditions for competing in today's world is self-confidence as well as openness to innovation that is different from the existing one, attracting attention and can mobilize other people and to have creative ideas. Being different from the existing one or being preferable when compared to the others is closely related to this innovation and creativity. It is stated that the definition of entrepreneurship was first made by Cantillon who was of French origin in 18th century. In this definition, it is emphasized that the person organizes the work to make a profit and takes the risk arising from the work (As citied Özmen, 2015). The person who can manage this is considered as an entrepreneur. In 1800, the French economist Say stated that entrepreneurs shifted economic resources from small areas to larger areas with higher productivity. He focused on more what an entrepreneur does rather than who she/he is (Drucker, 1986). From the past to the present, it is seen that entrepreneurship has the developments and changes that need to be adapted for the same purpose. For this reason, competitiveness can be associated with how high adaptation is. Sports environments are suitable areas for entrepreneurship, because sports sector offers many opportunities thanks to its nature. It is known that sports entrepreneurship has many roles in economic development and increasing welfare level of countries. When these roles are examined, it is seen that they are about business development, providing employment and prosperity as well as physical and mental health of society (As citied Gonzalez Serrano et al., 2017). Entrepreneurship can be realized in whatever field or sector it is only when individuals have some entrepreneurial characteristics. The fact that entrepreneurship is a social and cultural phenomenon will cause emergence of different characteristics in every society and culture. However, the following trends come into prominence when emergent characteristics in terms of societies and cultures in general find a common ground: Risk taking, self-confidence, need for success, 
innovation, creativity; good communication (Çetinkaya Bozkurt \& Alparslan, 2013). The focus of this study is on the status of coaches in reflecting these entrepreneurial characteristics to the sport field. The coaches, who are both educators and one of the important elements of the sports field also arouse curiosity about their entrepreneurial tendencies, because coaches can transfer their life styles to enterprises in line with their entrepreneurship tendencies and point out that training activities can be provided without profit making purpose (Jones et al., 2017).

In their study named "Entrepreneurial orientation of sport coaches in Gauteng Province, South Africa", Koloba and Surujlal (2013) examined the entrepreneurial tendencies of sports trainers in six factors as creativity, open-mindedness, determination, self-starter, risk taker, and discipline and entrepreneurial tendencies of sports coaches was found to be positive.

Entrepreneurial tendency is the readiness for behavioral tendencies, which suggests that the person chooses to focus on new areas of employment (Hermansen Kobulnicky\& Moss, 2004). According to Mitchell (2004), determining the factors that encourage individuals to focus on entrepreneurship is important because it causes an increase in entrepreneurship tendency. Similarly, sports coaches can engage in entrepreneurship activities such as consultancy services in schools, universities, sports clubs and the community in general. Therefore, they can use their knowledge and skills to educate young people when they need it most. Working hours of sports coaches, especially the trainers who train professional teams (mainly football coaches), are determined according to the success or failure of their teams in the club for which they work. Failure to achieve success for a few weeks tout de suite may result in termination of agreements between clubs and coaches. At this point, due to the uncertainty of employment, lack of employment, lack of guarantee of business continuity, short-term contracts, and unfavorable developments in career plans, coaches are being pushed towards entrepreneurship tendency. For these reasons, the number of entrepreneurs is increasing rapidly as many professional team coaches do not guarantee their business continuity. For this purpose, sports coaches should use their entrepreneurial tendencies in order to survive rather than relying on sports clubs. The personal sense of entrepreneurship of a sports coaches refers to an entrepreneurial tendency that is relevant to seeking opportunities and using them for personal or social gain (Surujlal, 2016).

From this point of view, in this study, it is aimed to examine the entrepreneurial tendencies of coaches in terms of demographic variables. For this purpose, answers for the following questions were sought:

Q1: What are the entrepreneurship tendencies of coaches?

Q2: Are entrepreneurship tendencies different depending on gender of coaches?

Q3: Are entrepreneurship tendencies different depending on age of coaches?

Q5: Are entrepreneurship tendencies different depending on working year of coaches?

\section{Method}

\subsection{The Sample of the Study}

The sample of this study, which was designed as a descriptive and quantitative study, is composed of a total of 130 coaches for various sports branches, 38 of which are female and 92 are male.

\subsection{Data Collection Tools}

In this study, "Entrepreneurship Scale" which was developed by Deveci and Çepni (2015) for teacher candidates was used as a data collection tool. This scale was chosen because coaches were responsible for their sporters' training. The scale consists of 38 items and five sub-dimensions. These dimensions are taking risks (7 items), self-confidence ( 7 items), being innovative ( 7 items), seeing opportunities ( 9 items) and emotional intelligence ( 8 items). Risk taking sub-dimension refers to taking risks in case of uncertainty; self-confidence sub-dimension refers to self-confidence in starting a job; being innovative sub-dimension refers to ability to produce new ideas; seeing opportunities sub-dimension refers to ability to see and invest in areas that can be profitable now or in the future and emotional intelligence sub-dimension refers to being aware of individual's own feelings and being able to manage them. The five items included in the scale are evaluated by reversing because they contain negative expression. Additionaly, the lowest 7, the highest 35 points is obtained from the sub-dimensions containing seven items; the lowest 8 , the highest 40 points is obtained from the sub-dimension containing eight items; and the lowest 9 , the highest 45 points is obtained from the sub-dimension containing nine items (Deveci\&Çepni, 2015).

\subsection{Data Analysis}

In the analysis of the obtained data, first Kolmogorow Smirnov test was used to determine the normality 
distribution and it was determined that it did not show normal distribution. For this reason, among non-parametric tests, Mann-Whitney U test was used for paired comparisons; Kruskal Walis H test was used for more than two comparisons and Mann-Whitney $U$ test was used manually to determine the source of meaningful difference. Descriptive statistics were also made.

\section{Results}

In this section, the research findings revealed by statistical analyzes are given in tables.

Table 1. Demographic information of coaches

\begin{tabular}{lllll}
\hline Variables & & $\mathrm{N}$ & $\mathrm{f}$ & $\%$ \\
\hline Gender & Female & 38 & 38 & 29.2 \\
Education Status & Male & 92 & 92 & 70.8 \\
& Middle School & 3 & 3 & 2.3 \\
& High school & 5 & 5 & 3.8 \\
& Undergraduate & 95 & 95 & 73.1 \\
Coaching Year & Pg Postgraduate & 27 & 27 & 20.8 \\
& 1-3 years & 36 & 36 & 27.7 \\
& 4-7 years & 37 & 37 & 28.5 \\
Coaching Sports & 8-11 years & 23 & 23 & 17.7 \\
& 12-15 years & 34 & 34 & 26.2 \\
& Hockey & 14 & 14 & 10.8 \\
& Volleyball & 25 & 25 & 19.2 \\
& Athleticism & 16 & 16 & 12.3 \\
& Football & 18 & 18 & 13.8 \\
& Pilates & 2 & 2 & 1.5 \\
& Handball & 5 & 5 & 3.8 \\
& Bocce & 4 & 4 & 3.1 \\
& Swimming & 6 & 6 & 4.6 \\
& Tennis & 23 & 23 & 17.7 \\
& Folk Dances & 4 & 4 & 3.1 \\
& Basketball & 3 & 3 & 2.3 \\
& Oryantring & 5 & 5 & 3.8 \\
& Fitness & 2 & 2 & 1.5 \\
& Archery & 3 & 130 & 2.3 \\
& & 130 & & 100.0 \\
\hline
\end{tabular}

The data collected from the sample, its demographical and descriptive information about the coaches were as follows: $70.8 \%$ were male, $31.5 \%$ were in the $36-43$ age range, $73.1 \%$ of Undergraduate graduates, about $19.2 \%$ were volleyball coaches, $28.5 \%$ had $4-7$ years of experience.

Table 2. Entrepreneurship tendencies of coaches

\begin{tabular}{llllll}
\hline Sub Dimensions & $\mathrm{N}$ & Mean & SD & Min. & Max. \\
\hline Risk Taking & 130 & 29.30 & 4.29467 & 14.00 & 35.00 \\
Self-Confidence & 130 & 29.68 & 4.23905 & 14.00 & 35.00 \\
Being Innovative & 130 & 28.18 & 4.38953 & 11.00 & 35.00 \\
Seeing Opportunities & 130 & 38.25 & 6.35672 & 19.00 & 74.00 \\
Emotional Intelligence & 130 & 33.31 & 5.02374 & 11.00 & 40.00 \\
\hline
\end{tabular}

When the means given in Table 2 in which descriptive statistics of coaches according to the sub-dimensions of the entrepreneurship tendencies were examined, it was determined that while they have kind of high entrepreneurship trends for sub-dimensions of self-confidence, risk taking, innovative and emotional intelligence, they have moderate entrepreneurial tendencies in the sub-dimension of seeing opportunities. 
Table 3. Mann Whitney U test results for entrepreneurial tendencies of coaches by gender

\begin{tabular}{lllllll}
\hline Sub Dimensions & Gender & $\mathrm{N}$ & Mean Rank & Sum of Ranks & $\mathrm{U}$ & $\mathrm{p}$ \\
\hline Risk Taking & Female & 38 & 70.03 & 2661.00 & & \\
& Male & 92 & 63.63 & 5854.00 & 1576.00 & .376 \\
Self-Confidence & Female & 38 & 70.53 & 2680.00 & & .326 \\
& Male & 92 & 63.42 & 5835.00 & 1557.00 & .835 \\
Being Innovative & Female & 38 & 66.57 & 2529.50 & & \\
& Male & 92 & 65.06 & 5985.50 & 1707.50 & .508 \\
Seeing Opportunities & Female & 38 & 68.89 & 2618.00 & & \\
& Male & 92 & 64.10 & 5897.00 & 1619.00 & .160 \\
Emotional Intelligence & Female & 38 & 72.70 & 2762.50 & & 1474.50 \\
& Male & 92 & 62.53 & 5752.50 & &
\end{tabular}

The results of the analysis of the entrepreneurship trends according to the gender of the coaches in terms of sub-dimensions are presented in Table 3. According to the table, no significant difference was found in the sub-dimensions of entrepreneurial tendencies as risk taking, self-confidence, being innovative, seeing opportunities and emotional intelligence in terms of gender of the coaches participating in the study $(p>0.05)$.

Table 4. Kruskal Wallis H test results for entrepreneurial tendencies of coaches by age

\begin{tabular}{lllllll}
\hline Sub Dimensions & Age & N & Mean Rank & df & $\chi^{2}$ & $\mathrm{p}$ \\
\hline Risk Taking & $20-27$ & 33 & 62.11 & 3 & 3.826 & .281 \\
& $28-35$ & 34 & 57.12 & & & \\
Self-Confidence & $36-43$ & 41 & 72.73 & & & .615 \\
& $44-51$ & 22 & 70.07 & & & \\
& $20-27$ & 33 & 62.08 & 3 & & \\
Being Innovative & $28-35$ & 34 & 61.96 & & & \\
& $36-43$ & 41 & 66.51 & & & \\
& $44-51$ & 22 & 74.23 & & & \\
& $20-27$ & 33 & 66.45 & 3 & & \\
Seeing Opportunities & $28-35$ & 34 & 62.19 & & & \\
& $36-43$ & 41 & 67.26 & & & \\
& $44-51$ & 22 & 65.91 & & & \\
& $20-27$ & 33 & 63.65 & 3 & & \\
\end{tabular}

Note. $\mathrm{p}<0.05$.

Table 4 shows Kruskal Wallis $\mathrm{H}$ test results of entrepreneurship tendencies according to coaches' age. According to the table, no significant difference was found in the sub-dimensions of entrepreneurial tendencies as risk taking, self-confidence, being innovative, seeing opportunities and emotional intelligence in terms of ages of the coaches participating in the study $(\mathrm{p}>0.05)$. 
Table 5. Kruskal Wallis H test results of entrepreneurship tendencies of coaches by coaching year

\begin{tabular}{|c|c|c|c|c|c|c|}
\hline Sub Dimensions & CoachingYear & $\mathrm{N}$ & Mean Rank & $\mathrm{df}$ & $\chi^{2}$ & $\mathrm{p}$ \\
\hline \multirow[t]{4}{*}{ Risk Taking } & $1-3$ years & 36 & 61.92 & 3 & 8.859 & $.031^{*}$ \\
\hline & $4-7$ years & 37 & 53.08 & & & \\
\hline & $8-11$ years & 23 & 73.57 & & & \\
\hline & $12-15$ years & 34 & 77.35 & & & \\
\hline \multirow[t]{4}{*}{ Self-Confidence } & $1-3$ years & 36 & 67.94 & 3 & 9.225 & $.026^{*}$ \\
\hline & 4-7 years & 37 & 50.26 & & & \\
\hline & $8-11$ years & 23 & 71.61 & & & \\
\hline & $12-15$ years & 34 & 75.37 & & & \\
\hline \multirow[t]{4}{*}{ Being Innovative } & $1-3$ years & 36 & 59.32 & 3 & 3.229 & .358 \\
\hline & $4-7$ years & 37 & 61.30 & & & \\
\hline & $8-11$ years & 23 & 72.59 & & & \\
\hline & $12-15$ years & 34 & 71.82 & & & \\
\hline \multirow[t]{4}{*}{ Seeing Opportunities } & $1-3$ years & 36 & 64.03 & 3 & 5.020 & .170 \\
\hline & 4-7 years & 37 & 55.43 & & & \\
\hline & $8-11$ years & 23 & 71.61 & & & \\
\hline & $12-15$ years & 34 & 73.88 & & & \\
\hline \multirow[t]{4}{*}{ Emotional Intelligence } & $1-3$ years & 36 & 67.04 & 3 & 0.900 & .826 \\
\hline & $4-7$ years & 37 & 60.80 & & & \\
\hline & $8-11$ years & 23 & 65.83 & & & \\
\hline & $12-15$ years & 34 & 68.76 & & & \\
\hline
\end{tabular}

Table 5 shows the results of the Kruskal Wallis $\mathrm{H}$ test conducted to determine whether the number of years of experience of being coaches make any difference in terms of their entrepreneurial tendencies. According to this, a significant difference was found in terms of in terms of the number of years of experience of being coaches in risk taking and self-confidence sub-dimensions $(p<0.05)$, and no significant difference was found in being innovative, seeing opportunities and emotional intelligence sub-dimensions ( $p>0.05)$. Mann Whitney $U$ test was performed manually to determine the source of the difference in risk taking and self-confidence sub-dimensions and the results were given in Table 6 and Table 7.

Table 6. Manual Mann Whitney $U$ test results for determining the source of differences in risk-taking sub-dimension according to coaching year of coaches

\begin{tabular}{|c|c|c|c|c|c|c|}
\hline Sub Dimension & CoachingYear & $\mathrm{N}$ & Mean Rank & Sum of Ranks & $\mathrm{U}$ & $\mathrm{p}$ \\
\hline \multirow[t]{12}{*}{ Risk Taking } & $1-3$ years & 36 & 39.44 & 1420.00 & & \\
\hline & 4-7 years & 37 & 34.62 & 1281.00 & 578.00 & .328 \\
\hline & $1-3$ years & 36 & 27.96 & 1006.50 & & \\
\hline & $8-11$ years & 23 & 33.20 & 763.50 & 340.50 & .251 \\
\hline & $1-3$ years & 36 & 31.51 & 1134.50 & & \\
\hline & $12-15$ years & 34 & 39.72 & 1350.50 & 468.50 & .090 \\
\hline & 4-7 years & 37 & 26.99 & 998.50 & & \\
\hline & $8-11$ years & 23 & 36.15 & 851.50 & 295.50 & $.047^{*}$ \\
\hline & 4-7 years & 37 & 29.47 & 1090.50 & & \\
\hline & $12-15$ years & 34 & 43.10 & 1465.50 & 387.50 & $.005^{* *}$ \\
\hline & $8-11$ years & 23 & 28.22 & 649.00 & & \\
\hline & $12-15$ years & 34 & 29.53 & 1004.00 & 373.00 & .768 \\
\hline
\end{tabular}

Note. ${ }^{*} \mathrm{p}<0.05,{ }^{* *} \mathrm{p}<0.01$.

According to the results of the manual Mann Whitney $U$ test conducted to determine the source of the difference in risk taking sub-dimension, a significant difference was determined in favor of those between 8-11 years for the coaches having between 4-7 years and 8-11 years of experience of being coaches $(p<0.05)$ and in favor of those between 12-15 years for the coaches having between 4-7 years and 12-15 years of experience of being coaches $(\mathrm{p}<0.01)$. 
Table 7. Manual Mann Whitney U test results for determining the source of differences in self-confidence sub-dimension according to coaching year of coaches

\begin{tabular}{|c|c|c|c|c|c|c|}
\hline Sub Dimension & CoachingYear & $\mathrm{N}$ & MeanRank & Sum ofRanks & $\mathrm{U}$ & $\mathrm{p}$ \\
\hline \multirow[t]{12}{*}{ Self-Confidence } & $1-3$ years & 36 & 42.22 & 1520.00 & & \\
\hline & 4-7 years & 37 & 31.92 & 1181.00 & 478.00 & $.037^{*}$ \\
\hline & $1-3$ years & 36 & 29.17 & 1050.00 & & \\
\hline & $8-11$ years & 23 & 31.30 & 720.00 & 384.00 & .639 \\
\hline & $1-3$ years & 36 & 33.56 & 1208.00 & & \\
\hline & $12-15$ years & 34 & 37.56 & 1277.00 & 542.00 & .408 \\
\hline & 4-7 years & 37 & 26.58 & 983.50 & & \\
\hline & $8-11$ years & 23 & 36.80 & 846.50 & 280.50 & $.027^{*}$ \\
\hline & $4-7$ years & 37 & 29.76 & 1101.00 & & \\
\hline & $12-15$ years & 34 & 42.79 & 1455.00 & 398.00 & $.008^{* *}$ \\
\hline & $8-11$ years & 23 & 27.50 & 632.50 & & \\
\hline & $12-15$ years & 34 & 30.01 & 1020.50 & 356.50 & .572 \\
\hline
\end{tabular}

According to the results of the manual Mann Whitney U test conducted to determine the source of the difference in self-confidence sub-dimension, a significant difference was determined in favor of those between 1-3 years for the coaches having between 1-3 years and 4-7 years of experience of being coaches $(\mathrm{p}<0.05)$, in favor of those between 8-11 years for the coaches having between 4-7 years and 8-11 years of experience of being coaches $(\mathrm{p}<0.05)$, and in favor of those between 12-15 years for the coaches having between 4-7 years and 1215 years of experience of being coaches $(\mathrm{p}<0.01)$.

\section{Discussion}

This study aimed to examine the entrepreneurial tendencies of coaches in terms of demographic variables. Considering the findings obtained for this purpose, it was found that entrepreneurship tendencies were medium or above medium in terms of sub-dimensions, that gender, age and level of training did not affect the entrepreneurship tendencies of coaches, and that the number of experience years of being coaches was an effective demographic variable in entrepreneurial tendencies.

The sports industry, depending on the characteristics of the sector and its place in the current economic market, needs entrepreneurs who have entrepreneurial characteristics and show their tendencies (González Serrano et al., 2017). In this respect, the coaches who are the actors in the sports sector can also show their entrepreneurship tendencies and assets. The coaches, who are the actors of the sports field, in the sports sector can have the opportunity to show their entrepreneurship tendencies and their assets. Being a trainer is a cognitive, managerial information system that provides the determination, continuity and efficiency of opportunities by combining information and methods presented to the person or group. For this reason, being a trainer is seen as an entrepreneurial support application that includes education, learning and advice (Salem \&Lakhal, 2018). The fact that entrepreneurship tendencies of trainers are in medium and above level in terms of sub-dimensions is considered compatible with entrepreneurship trends in six sub-dimensions that Koloba and Surujlal (2013) formed together with trainers in North Africa. Surujlal (2016) stated that trainers should develop an important point of view regarding entrepreneurship tendency by indicating that managers and supporters play an important role in the issue of whether to keep trainers in a sports club or not and that's why trainers are constantly under pressure. In addition to this, in the study performed by Seraslan and Ozman (2015) together with with sports management students, it was stated that students' entrepreneurship levels are high. Nas and Temel (2018), in their study aimed to determine the entrepreneurship levels of the students of the School of Physical Education and Sports; indicated that the level of entrepreneurship of students is generally high. In the study of entrepreneurial tendencies and personality traits students of of the School of Physical Education, it was found that there was a very high entrepreneurship tendency among the departments of sports management. Students studying in the training and coaching department have high entrepreneurial tendencies. On the other hand, Öztaş et al. (2017), determined that the university students who take sports training in their studies have a high level of entrepreneurship characteristics and tendencies. They also found a positive relationship between entrepreneurship characteristics and trends. González Serrano et al. (2017), in their study with university students who took sports training, also found that students' entrepreneurship tendencies were at a medium level. The finding in this study was found partially compatible with the level of being medium and above. It was found that the entrepreneurship characteristics of trainers do not differ in terms of their gender, age and level of training. Gender, age, and level of training all reveal that these characteristics are not important in the emergence of 
entrepreneurial characteristics. In their study they conducted with university students studying sports science, Şeşen and Basım (2012) found that entrepreneurship characteristics differ by gender, but also do not differ by age. While the findings of this study were found compatible with age; it was not found compatible with gender. Karabulut and KaracanDoğan (2018) found in their study in which they examined university students' entrepreneurial tendencies and general competence levels that there is no difference according to gender. On the other hand, in the study Sezer (2013) conducted with university students, it was stated that gender did not have an impact on entrepreneurial intention.In their research, Nas and Temel (2018) showed that entrepreneurship tendency does not differ according to gender and age. The findings of the studies mentioned are consistent with the results of the study. Durak (2018) stated that entrepreneurship intentions of university students differed according to gender and that male students had higher entrepreneurship intentions than female students. According to the study of entrepreneurship tendency applied by Turkmen and İşbilir (2014) to sports management students, it is stated that male students have higher entrepreneurial tendencies than female students. Alparslan et al. (2017) examined effect of cultural values of university students on entrepreneurship tendency in their study and found that male students had higher entrepreneurial tendency than female students. The result of the study is not found compatible with these findings. In Karataş's (2018) study, that there is no significant difference between male and female students, in terms of age variable; as the age increases, entrepreneurship tendency has increased. Salik and Kaygin (2016), in their study, found that university students' entrepreneurial tendencies were higher in the risktaking sub-dimension of those aged 26 and older. Considering the coaches who have graduated from the coaching departments of the universities, or the coaches who are trained in coaching courses, the fact that the lessons related to entrepreneurship are not included in the departments and courses suggest that the coaches may be the result of an educational deficiency that will shape the entrepreneurship tendencies.Although, today it is known that many people attempt to start a work in line with their entrepreneurship characteristics though their different gender and age, it is regarded normal that gender and age variables do not make any difference. In terms of level of coaching, it is regarded normal that there is no difference in the entrepreneurial characteristics of the 1st level coaches, because in order to make any space and to start an enterprise, it is required to be at least 2 nd level coach. On the other hand, it is surprising that no difference was found in the 2nd level, 3rd level and 4th level coaches. This finding is thought to be due to the fact that the coaches in this level could be satisfied with their work so far and they do not want to seek extra quests. It is also believed that the extra cases not covered herein may have an effect on this.

In the study, it was found that the entrepreneurship characteristics of coaches differed in terms of the number of experience year of being coaches in risk taking and self-confidence sub-dimensions. It was found that in the risktaking sub-dimension the trainers having experience of being coaches between 8-11 years and 12-15 years have the characteristics of taking higher risk; in the self-confidence sub-dimension the coaches having experience of being coaches between 1-3 years, 8-11 years, and 12-15 years have higher self-confidence. It was observed that coaches did not take risks in the first years and they gained self-confidence in the first years. This finding shows that while coaches often have self-confidence, risk-taking is a feature that emerges with experience. This is thought to be connected to the increase in the ability to cope with the situations encountered as a result of experience.

\section{Results}

As a result, it was found that the entrepreneurial characteristics of coaches were at medium and above level; risk taking and self-confidence were related to the number of years of experince of being coaches. According to this result, in addition to the variables discussed in the study, it is advisable to make new studies by including different variables that may affect entrepreneurial characteristics.

\section{References}

Alparslan, A. M., Taş, M. A., \& Yastoğlu, S. (2017). Girişimcilik niyeti eğitimle mi artar yoksa kültürel değerlerle mi açıklanır? Mehmet Akif Ersoy Üniversitesi Sosyal Bilimler Enstitüsü Dergisi, 9(21), 148-161. https://doi.org/10.20875/makusobed.311163

Çetinkaya Bozkurt, Ö., \& Alparslan, A. M. (2013). Girişimcilerde bulunması gereken özellikler ile girişimcilik eğitimi: Girişimci ve öğrenci görüşleri. Journal of Entrepreneurship and Development, 8(1), 7-28.

Deveci, İ., \& Çepni, S. (2015). Öğretmen adaylarına yönelik girişimcilik ölçeğinin geliştirilmesi: Geçerlik ve güvenirlik çalışması. International Journal of Human Sciences, 12(2), 92-112. https://doi.org/10.14687/ijhs.v12i2.3240

Drucker, P. F. (1986). Innovation and entrepreneurship. New York: Harper. 
Durak, İ. (2018). Girişimcilik niyeti ile duygusal zekâ ve bazı sosyo-demografik değişkenler arasındaki ilişki: üniversite öğrencileri üzerine bir araştırma. MANAS Sosyal Araştırmalar Dergisi, 7(1), 281-297.

Gonzalez Serrano, M. H., Hervas, J. C., Perez Campoz, C., \& Calabuig Moreno, F. (2017). The importance of developing the entrepreneurial capacities in sport sciences university students. International Journal of Sport Policy and Politics, 9(4), 625-640. https://doi.org/10.1080/19406940.2017.1316762

Hermansen Kolbulnicky, C. J., \& Moss, C. L. (2004). Pharmacy student entrepreneurial orientation: A measure to identify potential pharmacist entrepreneurs. American Journal of Pharmaceutical Education, 68(5), 1-10. https://doi.org/10.5688/aj6805113

Jones, P., Jones, A., Williams Burnett, N., \& Ratten, V. (2017). Let's get physical: Stories of entrepreneurial activity from sports coaches/instructors. The International Journal of Entrepreneurship and Innovation, 18(4), 1-30. https://doi.org/10.1177/1465750317741878

Karabulut, E. O., \& Karacan Doğan, P. (2018). Investigation of entrepreneurship trends and general competency levels of university students studying at faculty of sports sciences. Journal of Education and Training Studies, 6(4), 212-220. https://doi.org/10.11114/jets.v6i4.3128

Karataş, İ. (2018). Beden Ĕgitimi ve Spor Yüksekokulu öğrencilerinin kişilik özelliklerinin girişimcilik eğilimleri üzerindeki etkilerinin incelenmesi: Bartın Üniversitesi örneği. Yayımlanmamıș Yüksek Lisans Tezi. Bartın Üniversitesi, Bartın.

Koloba, H. A., \& Surujlal, J. (2013). Entrepreneurial orientation of sport coaches in Gauteng Province, South Africa. African Journal for Physical, Health Education, Recreation and Dance (AJPHERD), 2, 133-144.

Mitchell, B. C. (2004). Motives of entrepreneurs: A case of South Africa. Journal of Entrepreneurship, 13(2), 167-183. https://doi.org/10.1177/097135570401300203

Nas, K., \& Temel, V. (2018). Beden Eğitimi ve Spor Yüksekokulu öğrencilerinin girişimcilik düzeyleri. Atatürk Üniversitesi Beden Eğitimi ve Spor Bilimleri Dergisi, 20(3), 134-144.

Nova, J. (2015). Developing the entrepreneurial competencies of sport management students. Procedia - Social and Behavioral Sciences, 174, 3916-3924. https://doi.org/10.1016/j.sbspro.2015.01.1134

Özmen, Ç. (2015). Rekreasyon ve spor yöneticiliği ögrrencilerinin girişimcilik düzeylerinin değerlendirilmesine yönelik bir çalışma. Yayımlanmamış Yüksek Lisans Tezi. Mehmet Akif Ersoy Üniversitesi, Burdur.

Öztaş, M., Kasımoğlu, B., \& Şirin, E. F. (2017). The effect of entrepreneurial personality traits of undergraduates in the area of education of physical education and sports on the entrepreneurship tendency. International Journal of Human Sciences, 14(4), 4365-4382. https://doi.org/10.14687/jhs.v14i4.4918

Salem, A. B., \& Lakhal, L. (2018). Entrepreneurial coaching: How to be modeled and measured? Journal of Management Development, 37(1), 88-100. https://doi.org/10.1108/JMD-12-2016-0292

Salik, N., \& Kaygın, E. (2016). Demografik değişkenler açısından üniversite öğrencilerinin girişimcilik eğilimlerinin belirlenmesi: Kafkas Üniversitesi örneği. KSÜ Sosyal Bilimler Dergisi, 13(1), 145-162.

Seraslan, M. Z., \& Ozman, C. (2015). Investigation of entrepreneurship levels of university students studying at sports management departments in terms of some variables. Journal of Health, Sport and Tourism, 6(1), $50-55$.

Sezer, C. (2013). Kariyer olarak girişimcilik ve girişimcilik niyetini etkileyen faktörlerin içerik analizi ile belirlenmesi. MANAS Sosyal Araştırmalar Dergisi, 2(2), 49-60.

Surujlal, J. (2016). Influence of outlook towards work on entrepreneurial potential of professional sport coaches in South Africa. Procedia Economics and Finance, 35, 597-603. https://doi.org/10.1016/S2212-5671(16)00073-3

Türkmen, M., \& İşbilir, U. (2014). Üniversite öğrencilerinin girişimcilik eğilimlerinin sosyodemografik özellikler açısından incelenmesi. CBÜ Beden Eğitimi ve Spor Bilimleri Dergisi, 9(2), 18-28.

\section{Copyrights}

Copyright for this article is retained by the author, with first publication rights granted to the journal.

This is an open-access article distributed under the terms and conditions of the Creative Commons Attribution license (http://creativecommons.org/licenses/by/4.0/). 